\title{
The Effect of Using We6-Quest strategy on Developing Reading Comprehension Performance for EFL Students, October 6 University
}

\section{Eman Sedik Sayed}

MA Candidate, October 6 University

\section{Abstract:}

The main aim of this study is to measure the effect of using web-quest strategy on developing reading comprehension performance for EFL students. The study participants were English majors at the Faculty of Education, October 6 University. The study participants involved only third year English language majors who are expected to be highly aware of reading comprehension performance. To collect the required data, a reading test was designed, validated and administered. The administration of the study instruments happened in their second term of the academic year 20192020. The participants of the present study were asked to respond to a reading comprehension test (RCT) through using web-quest strategy. Results showed that 45,5\% of the study participants were unable to pass the reading comprehension test (RCT) while, $54.5 \%$ were able to pass the reading comprehension test (RCT).Finally, some suggestions and recommendations were proposed to improve reading comprehension performance through using web-quest strategy.

Keywords: Web-quest strategy, reading comprehension performance (RCP), EFL students.

\section{Introduction :}

Computer Assisted Language Learning (CALL) has engaged the interest of many educators and researchers in order to simplify learning a foreign language. Yet, the Internet applications nowadays add more value to technology-based Education. WebQuests encourage students to surf on several online resources and help them to gain information about a specific topic. The experimental group received traditional teaching plus WebQuests as auxiliary activities. The control group 
received the traditional teaching only. The students' comprehension performance in the post-test was compared for both groups in order to determine whether there were significant differences between the groups in relation to the treatment. Significant differences occurring in the experimental group's post-test comprehension performance when compared to the pre-test indicate that using WebQuest can improve students' reading comprehension performance. The results indicate that WebQuests have possibility for use in enhancing reading comprehension. Teachers and students do, however, need to be drilled in order to use WebQuests more efficiently (Alshumaimeri, 2018; Kern, 2016).

In their study, Teclehaimanot and Lamb (2014) asserted that the use of technology in teaching and learning could bring reading alive for children and young adults. They indicated that Web-quests could engage students in problem-solving and collaboration. Results revealed that a Web-quest environment could facilitate the reading experience and help students meet challenging standards while addressing critical questions that bring meaning to learning.

Rozema (2014) designed a study that described how two Web-based learning tools, the literary MOO and the Webquest, were used to reinforce reader-oriented and textoriented literature instruction. Results revealed that the literary $\mathrm{MOO}$, used in conjunction with the novel Brave New World, helped students evoke and elaborate on the story world of the text, make personal connections between the text and their own lives, and discuss the text in a collaborative way. Results also showed that the Web-quest, used in conjunction with the novel Heart of Darkness, helped the students read the text in an analytical and textcantered way. 
Tsai (2015) conducted a study which aimed at measuring reading vocabulary acquisition and reading performance of EFL students when a Web-quest learning module was used to develop traditional EFL reading instruction. This study also aimed at investigating the relationship between student attitudes and student perceptions toward the use of the Web-quest learning module. Results showed that the experimental group outperformed the control group as a result of using the Web-quest in traditional EFL reading instruction with significant difference in their vocabulary acquisition and story reading performance, but not in their thematic reading performance. Moreover, the results of survey revealed a positive attitude toward the Web-quest learning module and a significant correlation was reported between student attitudes and student perceptions.

Prapinwong (2018) designed a study which aimed at exploring the teacher's and students' use of Web-quests in an EFL context. Results showed that the students made a statistically significant gain in the vocabulary tests in both units and that the type of tasks influenced different learning outcomes. The teacher expressed the positive aspects and challenges concerning the use of Web-quests regarding the underlying principles and methods embedded in the tool as well as the constraints of the curriculum and assessment. Students' perceptions revealed the different levels of students' engagement and reaction with the Web-quest group tasks, and their experiences with the online reading. Finally, the study provided recommendations for adopting Web-quests in the EFL classrooms.

So, it could be concluded that many educational institutions use computers and the Internet as part of a language classroom. Computer Assisted Language Learning (CALL) fields provide students with access to a large number of authentic learning resources and 
opportunities to react with other speakers of the language. In order for students to find beneficial information on the Web, they need to read extensively, evaluate content of texts, select pertinent information, and synthesize materials to organize and structure meaning. They also have opportunities to use the target language through reading, writing presentations, listening to peers' opinions, and discussing ideas on motivating issues. Very little research has been conducted on WebQuest use in the EFL classroom to investigate its potential in enhancing language skills and reading skills at university level in particular. Therefore, this study will try to shed light on the possible effects of WebQuest on the comprehension performance of tertiary level of students in EFL context. This study is hopefully significant for teachers, students, EFL and CALL fields, in that it provides language teachers with information about teaching reading skills using WebQuest strategy.

\section{Literature Review :}

WebQuest was designed by Bernie Dodge and Tom March in 1995 in an effort to integrate the World Wide Web into classrooms. Exposed to several online resources, students are required to gather information about a specific topic (Dodge, 1997). Sometimes these resources are supported with video conferencing in order to enhance understanding (Koenraad, 2004). WebQuests are designed to provide an opportunity for students to exchange real information and thus trigger meaningful communication. A WebQuest involves team work among groups of students accessing the web in order to gather information and reproduce it in different forms (March, 2004).

As described by March (2004), the main element of a WebQuest is "a scaffolding structure that encourages students motivation and simplifies advanced thinking with 
integration of enriched learning resources" (p. 02). Samuda and Bygate (2010) considered WebQuest a web-based task and link it to task-based learning and teaching as tasks on a broad range of topics are used throughout the curriculum. Using WebQuest gives students the opportunity to be exposed to many resources while they are in the classroom. As such, Dodge (2006) suggested students engaging with the method develop a deeper understanding of the content when compared to the usual way of learning.

Similar conclusions have also been found in studies of other web based learning tools, such as online training courses, wikis, discussion forums, and videos (Bravo, Enache, Fernandez \& Simo, 2005; DeWitt \& Siraj, 2010; Limniou\& Whitehead, 2007). Dodge (1997) recommended that a WebQuest include the following basic structure: introduction, task, process, evaluation, and conclusion. In order to complete a WebQuest task, students search through links provided on the WebQuest. These links are relevant to the topic and are thus effective and focused learning tools. The students do not need to use general search engines as their primary source, so they do not run the risk of accessing inappropriate materials (March, 2010). The WebQuest task requires student analysis, synthesis, evaluation, judgment, problem solving and creativity (Dodge, 2011; Perkins \& McKnight, 2011). WebQuest, being a technological innovation, was found by teachers to be an up-to-date strategy that provides knowledge to students in an interesting way (Vidoni\& Maddux, 2012).

Moreover, motivation is considered to be an important psychological element in learning, plays an important role in students' ability to fulfil long-term goals (Guilloteaux \&Dörnyei, 2013). Dudeney (2014) suggested WebQuests are motivating, authentic tasks that require students to 
converge. Students in all grades, when questioned, indicate they prefer WebQuest to traditional teaching methods (Abbitt\&Ophus, 2008; Halat\&Peker, 2011; Noordin, Samed\& Razali, 2008; Prapinwong, 2008; Puthikanon, 2009). Students may enjoy and remember lessons far better via WebQuest than through the traditional way of learning (Hassanien, 2006).

The teacher's role is to guide students on how to use WebQuests in ways that evolve positive educational results. Teachers, by enclosure WebQuest technology, can elevate student interest in diverse subject matters while concurrently elevating the educational support their students in a mingled learning classroom. Blended learning can be an efficient teaching method that is not only viewed positively by students, but also supports successful learning outcomes (Tavukcu, Gezer \&Ozdamli, 2010). As such, teachers continue to play an important role in the blended learning classroom, as students do report having a positive view of face-to-face learning interaction in addition to online learning tools (Tuncay\&Uzunboylu, 2010).

According to Torres (2009), using WebQuest in learning has many advantages. Initially, it enhances the effective use of time; students use the links given by the teacher and search for information in a structured effective manner. A further benefit of WebQuest use in learning is that it supports higher-order thinking. Students are required to read, think, analyse, synthesize, and evaluate (Halat\&Peker, 2011; Torres, 2007). Chang, Chen, and Hsu (2011), in demonstrating the impact of different teaching strategies on the learning performance of environmental education, found WebQuest embraced students' critical thinking skills by encouraging different learning tasks and expression of opinions. In a study identifying the underlying constructs of WebQuests as perceived by 
teachers, Zheng, Perez, Williamson and Flygare (2009) found three constructs to be critical to WebQuests: constructivist problem solving, social interaction and scaffolded learning. This finding suggests that instead of focusing on critical thinking skills, emphasis could be placed on constructivist learning that incorporates critical thinking and knowledge application (Zheng et. al., 2012).

Segers and Verhoeven (2015) suggested that WebQuest can be seen as a method that helps organize the learning process in accordance with the theory of dialectic constructivism.

Investigating the effects of WebQuest on learning in elementary school classrooms, Segers and Verhoeven (2011) found the importance of learning from a WebQuest was moderate to high, as it offers a structured method by which students can surf on the Internet. This structure particularly benefited boys who learned more using WebQuest as opposed to a free search environment .Many studies have found that using WebQuest enhanced pivotal cooperation and collaboration among students (Gorghiu, Gorghiu, González, \& García de la Santa, 2006; Lara \& Repáraz, 2007; Murray \&Mcpherson, 2009; Torres, 2007).

By working collaboratively, students improve speaking skills through verbal interactionwith peers. When students work in groups they discuss assignments thereby exchanging vocabulary. According to Torres (2007), the use of WebQuest has the ability to enhance collaboration and cooperation among students while using the target language. This interaction in turn enhances responsible and independent learning. Gorghiu, Gorghiu, González, and García de la Santa (2006) found the greatest benefit of WebQuest was students' motivation and cooperative work. Students, as actors in the learning process, assume various 
roles in the WebQuest team. Students displayed greater enthusiasm playing specific roles and relaying information to group partners.

From the above words, it could be concluded that Working in groups is beneficial in that it gives students the opportunity to teach and assess each other and to correct each other's mistakes. It makes them feel mature and responsible for the group as a whole in addition to building social skills.

Central to Web-quest and EFL, web-Quests can be an effective and important tool to promote different foreign language skills. As discussed by Torres (2012), students are exposed to a large number of resources through the web. They read in the target language and then provide a written report of what they learned in the target language. As many EFL students do not enjoy reading in a second language, it is useful to employ motivational learning tools such as WebQuest in the second language classroom. Although Gaskill, McNulty and Brooks (2006) found no discernable difference in learning outcomes when WebQuests were compared to traditional methods, they did find that both teachers and students enjoyed and spoke highly of WebQuest instruction. Similar to the findings of Zheng et al., Barros and Carvalho (2007) found WebQuest to be a valuable environment for teaching extensive reading as it can support motivation and promote constructivist learning. "Talen Quest", or Language Quest in English, was developed as a tool for foreign language instruction (Koenraad \& Westhoff, 2010). It is an adaptation of the Web-Quest format designed to meet the needs of second language learners (Samuda \& Bygate, 2014). It encourages scaffolding activities by blending focus guides, text tools and strategy guidance. In relation to Web-Quest's usefulness in enhancing reading skills, Tsai (2006) 
investigated, in a quasi-experimental study, the effects of Web-Quest use on reading vocabulary acquisition and reading performance of Taiwanese EFL university students. The WebQuests were used to enhance the normal reading instruction practice in EFL reading courses. The results showed that the students in the treatment group (using WebQuests) significantly outperformed those in the control group (traditional reading class) in both their vocabulary learning and story reading comprehension. However, there were no significant differences in student thematic reading comprehension. The finding suggested that engagement of WebQuest in EFL reading instruction can be important in promoting students' story reading comprehension and vocabulary acquisition. While the abovementioned research reinforced the position that WebQuest can be an effective learning tool, students' perceptions of the tool are equally important in considering its widespread use.

Specifically investigating the effects of a WebQuest Writing Instruction program on Taiwanese EFL learners' writing performance, Chuo (2007), found that students in the WebQuest class improved their writing performance significantly more than those in the traditional writing class. Also investigating writing apprehension and perception of web-resource integrated language learning, Chuo (2007) found that the participants had a suitable perception of the WebQuest program and reported exploring more advantages than disadvantages. These findings showed the engagement of web resources, such as WebQuest, into EFL writing instruction can be efficient supporting students' writing performance and enhancing a positive learning experience. However, a comparable study on the engagement of WebQuest in Turkish EFL university classrooms found the experimental group and the control group scored equally on writing tests (Kocoglu, 2009). 
Koenraad and Westhoff (2010) suggested that the task should encourage use of the target language either in the form of language instruction, or of the language used in the Language Quest end products, or a combination of both. Koenraad and Westhoff (2010) suggested that the material used should be authentic and reflect what learners would apply in their real life.The task should reinforce collaboration and meaningful communication. Furthering research on the use of WebQuests in the EFL classroom, Researchers (Luźon-Marco, 2010; Sen \& Neufeld, 2015) found that WebQuest, being a web-based task oriented tool, helps students engage with texts related to their discipline, prepare for autonomous learning, and become accustomed to the methods of meaning construction needed in digital learning. Reporting similar conclusions, Noordin, Samed and Razali (2016) suggested that WebQuest techniques, with a solid instructional establishment, make use of global communication by sharing information and fostering discussion while participating to the combination of the internet in EFL learning. These authors surveyed a group of Malaysian student teachers in a TESL program. A questionnaire was administered to elicit their perceptions on the practicality and potential of Web-Quest in EFL classrooms. The findings showed that the plurality of the student teachers found WebQuest beneficial to English learning. Students were found to work and react with one another using English while engaging with reading materials, taking part in discussions, and presenting written work. These activities, as encouraged by Web-Quest, improve the students' level of language ability.

In addition to the acculturation to the digital age that students gain from Web-Quest, the effectiveness of WebQuests in second language learning also has been the subject of various empirical studies. Laborda (2016) investigated the effectiveness of WebQuest in English for 
Specific Purposes (ESP) classes (such as tourism). Laborda (2016) noted that in completing the WebQuest assignment, students read different materials and then come up with their own. This process gives students opportunities to discover how the target language is used and then spontaneously use the language in its correct way. Students are supplied with interactive opportunities which make the learning experience meaningful. In a similar classroom environment, Luzon (2017) supported Web-Quest use in ESP classes. She suggested that WebQuest is beneficial in ESP classes because it helps students use background knowledge from their discipline to assess the problem, evaluate information from different sources and synthesize a response to the main WebQuest problem.

Moreover, WebQuests effectiveness in enhancing writing skills, research suggested the tool can be effecient in promoting critical thinking skills. Puthikanon (2017) investigated the use of WebQuest by EFL university students in Thailand. Two WebQuests were used as supplementary reading activities in a reading course. The results showed that students used critical thinking during the Web-Quest at a high level. They actively analyzed, synthesized, evaluated, and reflected on information pertaining to the topic of the WebQuest. However, low proficiency students struggled to transfer their thoughts and opinions in the end products of the WebQuest. Nonetheless, findings suggested that Web-Quest can be a useful activity to promote critical thinking in an EFL reading course.

Prapinwong and Puthikanon (2017) investigated that students' perceptions of WebQuest in a college-level reading course in Thailand. The findings showed that students had mixed opinions toward WebQuest. Some students showed positive attitudes and experienced 
WebQuest as a fun activity that helped them to learn English. However, some students found the materials in the WebQuest to be overwhelming and felt disappointed when completing the WebQuest task. However, in a similar context, Prapinwong (2017) used two WebQuests with a group of students in a reading course at a university in Thailand. The findings showed that the teacher and students felt very positively toward the WebQuest experience.Additionally, the use of WebQuest in Prapinwong's (2017) study showed statistically significant positive effects in vocabulary learning among students.

So, it could be concluded that WebQuest considered as one of the important ways to engage technology into learning. Technology is replicating rapidly and teachers can improve classroom education by fostering different teaching methods that make their classes interesting and beneficial. WebQuest has been studied in terms of its effectiveness in language learning as discussed above.

\section{Context of the problem}

The problem of the study was derived from some sources such as:

The researcher, as a senior lecturer at the faculty of Education October 6 University, noticed that there was a deficiency in reading comprehension performance skills of third grade English majors at the faculty of Education, the department of English which may impede reading skills in general among students themselves and their teachers on the other hand within the educational situation. The researcher further noted that methodologies applied in teaching reading comprehension performance skills are traditional since they have no focus on application of the internet apps. Therefore, the researcher investigated previous studies that dealt with a development of reading 
comprehension performance skills of third grade English majors. She further stated that in spite of the importance of these skills there's a deficiency in applying them as there's no proper interest in these skills within teaching English. This on the other hand, what the researcher's exploratory study concluded to determine which students have a difficulty in acquirement of reading comprehension performance skills, through a diagnostic statically test done by the researcher; Results of the test revealed that $70 \%$ of students have a difficulty regarding their acquirement of reading comprehension performance skills. Moreover, conducting personal meetings with English majors concerning the reading comprehension performance skills of students demonstrated that there was insufficiency these skills for third grade English majors at different levels which led the researcher to apply more modern technological methods through a development of reading comprehension performance skills via using Web Quest strategy.

\section{Statement of the Problem}

Most of $3^{\text {rd }}$ year students English majors face difficulties in Reading comprehension performance at October 6 university because of using traditional teaching methods. Hence, this study aimed to measure the effect of using web-quest strategy on developing reading comprehension performance for EFL students.

\section{Study Questions}

This study aimed to investigate the effect of using Webquest strategy on developing reading comprehension performance for EFL students. It seeks to answer the following questions:

1-What are the required Reading performance skills for English majors at the faculty of Education, October 6 University? 
2- What's the proposed web quest strategy framework to develop Reading performance skills for English majors at the faculty of Education, October 6 University?

3- What is the effectiveness of web quest strategy on developing the Reading performance skills for English majors at the faculty of Education, October 6 University?

\section{Hypotheses of the Study}

The study attempted to test these following hypotheses:

1-There are statistically significant differences between the mean scores of the experimental group and The control group on the pre-administration of the test of Reading Comprehension Performance skills.

2-There are also statistically significant differences between the mean scores of both the experimental group and the control group on the post-administration in Reading Comprehension Performanceskills test in favor of the experimental group.

3-There are statistically significant differences between the mean scores of the experimental group on the pre and post administrations in Reading

Comprehension Performanceskills test in favor of the latter.

\section{Aims of the Study}

\section{The study attempted to achieve the following} objectives:

1-To investigate The Effect of Using Web-Quest strategy on Developing Reading Comprehension Performance For EFL Students.

2-To identify the most common innovative strategies used by prospective lecturers in October 6 University in developing reading comprehension performance.

3-To develop reading comprehension performance test. Significance of the Study

The significance of this study is derived from the following: 
1-This study may be considered a useful study of which tackled the connection between webquest and reading comprehension performance.

2-The outcomes of the study may be helpful in account of improving teaching of reading skill

within sub-skills in some Education faculties.

\section{Methodology :}

\section{Research Design}

The design of this study is a quasi-experimental (field experiment) since it was not feasible to randomly assign subjects to treatments (Cohen, Manion \& Morrison, 2010). It uses a pre-test/post-test quasi-experimental nonequivalent control group research design. This type of design is often used in educational research as it is not possible to assign subjects randomly to groups (Ary, Jacobs, \&Razavieh, 2002). That is, the groups were naturally assembled through their class sections. The experimental group received the traditional teaching plus WebQuests as supplementary activities. The control group received the traditional teaching only. The students' comprehension performance in the post-test was compared for both groups in order to determine whether there were significant differences between the groups in relation to the treatment.

\section{Participants}

This study is conducted in October 6 University for the English majors of English at faculty of education in the second term of the academic year 2019-2020. The study participants involved only third year English language Majors that should be highly aware of the courses of webquest and reading comprehension performanceThe participants were 70students. Students were enrolled in the Intensive English program with 10 weekly contact hours for the second term of the academic year 2019-2020. The program aims to develop students' English language 
proficiency and equip them with the essential language skills needed for academic study and future professional life. There are six levels of proficiency in the program where level six is for advanced learners and level one is for false beginners. Level three is considered pre-intermediate. The students were selected using a simple random selection and two sections were chosen to participate. There were 35 students in the experimental group and 35 students in the control group. The two sections were used for a total of 10 sessions (50 minutes each) over a seven week period in the second term of the academic year 2019-2020.In order to ensure that the subjects in this study were at the same proficiency level in reading comprehension, a reading comprehension pre-test was assigned to both groups. The results of the pre-test showed that the mean averages of the subjects' grades on the pre-test were very similar (see Table 1).

Table 1. t-test Results for the Groups' Equivalence

\begin{tabular}{|c|c|c|c|c|c|}
\hline Group & No. & Mean & $\begin{array}{c}\text { St. } \\
\text { Deviation }\end{array}$ & t. Value & $\begin{array}{c}\text { Sig. (2 } \\
\text { Tailed) }\end{array}$ \\
\hline Control & $\mathbf{3 5}$ & $\mathbf{1 5 . 9 0 2 4}$ & $\mathbf{5 . 8 1 2 6 4}$ & $\mathbf{0 . 7 6}$ & $\mathbf{0 . 9 8 7}$ \\
\hline Experimental & $\mathbf{3 5}$ & $\mathbf{1 5 . 8 5 7 1}$ & $\mathbf{5 . 8 5 6 1 9}$ & $\mathbf{0 . 7 6}$ & $\mathbf{0 . 9 8 7}$ \\
\hline
\end{tabular}

These results were computed through Independent Samples Test (t-test) and revealed at the $p<.05$ level in scores for the two groups $[t=0.35, p=0.972]$.

\section{Instruments}

\section{1-Reading comprehension Test :}

A pre- and post-reading comprehension tests were prepared in this study in order to measure the students' performance before and after the treatment. The full exam is usually taken during the final exams for the students of this study in this level. In this test, the students are provided with a passage to read carefully in order to discern the topic and general meaning of the text, the writer's purpose and the meaning of the text as a whole. Then, the students answer 
five questions with four-option multiple choice answers. The focus is on reading for detailed comprehension: understanding attitude, opinion, and writer purpose as well as reading for gist, inference and global meaning (Cambridge University ESOL Examination, 2009). A reliability analysis was computed for each test using the test/retest method (Cohen, Manion, \& Morrison, 2007). The reliability results were (Pearson coefficient) $r=0.698$ for the first test and $\mathrm{r}=0.725$ for the second test. to evaluate the validity and reliability of Reading comprehension test, the three EFL specialists revised the test and confirmed its validity and authenticity. To add, the test was conducted twice for the purpose of assessing the reliability of Reading comprehension test. It was conducted on the $20^{\text {th }}$ of July 2020 to 35 English language majors at October 6 University. Furthermore, it was re-conducted after a week on the same students. The researcher employed the testretest procedure in order to calculate the Reading comprehension test reliability through the application of web-quest strategy.Regarding the administration of the test, the Reading comprehension performance was conducted on Sunday in $19^{\text {th }}$ July 2020 at the October6 University within the second semester of the academic year 2019-2020. Students were given the test addition to systematized formal test papers. In the aftermath of the test, answers of the students were gathered. The duration of the test was an hour. On the other hand, the overall score of the Reading comprehension performance was 40 scores.

\section{Program Content:}

The web-quest strategy used in this study was designed by the researcher. The Web-quest inquiry designed was sent to three experienced EFL specialists to check for appropriateness for the students' level of proficiency and topic. Also, it was reviewed by two educational technology professors for its face validity. In web-quest strategy, there 
is two main pages, the teacher's and the student's. The student's page includes five parts. The first part is the introduction which gives general information in a motivational way about the whole Web-quest. The second part is the task which is a description of what the students should do. The third part is the process and it includes detailed steps describing what exactly the students are required to do. The fourth is the evaluation part which includes a rubric that shows the students how they will be evaluated. It includes the certain points they should accomplish at the end of the task. The final part is the conclusion which provides the students with further websites if they want to read more about the topic. The other page is the teacher's page which includes instructions for teachers who will use the Web-quest in general.

The Web-quest topics were chosen according to the students' level. The researcher tried to use various topics interesting to university level students. Those students interested in technology were expected to enjoy the 'Google It' Web-quest while those with an interest in sea animals might prefer 'The Killer Whales' Web-quest. Also included in the study was a 'Physical Activity' Web-quest which encourages students to integrate physical activity in their daily routines. The last Web-quest included in the study was an awareness raising Web-quest on Alzheimer's disease. Students need two to three sessions to complete the task in each Web-quest, depending on the students' level and motivation. Each session is 50 minutes. The researcher displayed the Web-quest topics on the white board and assigned students into groups. Each group worked on one computer. First, the researcher presented the Web-quest's homepage on the class white board explaining every part clearly in order to help students complete the task carefully and answer the questions. 
Following this instruction, students worked alone. The researcher's continued presence was, however, important as he is often called on to answer questions and address technical problems.

\section{Data Collection:}

In the first week, both the experimental group and control group received the pre-test before the treatment and instruction. The data collected was analysed using SPSS and a t-test was computed to ensure the groups equivalence. The treatment period was two weeks. During the treatment period, the experimental group received researcher-designed Web-quests embedded as supplementary materials in the traditional way of instruction. Web-quest took two sessions a week. The control group received only the traditional instruction. In week two, both the experimental and control group students received the post-test. The data collected was again analysed using SPSS. Then, paired sample t-tests were computed for the results of both groups in order to investigate the differences between the pre-test and posttest in comprehension performances.

An analysis of covariance (ANCOVA) was conducted in order to investigate the differences between the experimental and control group in the post-test. The ANCOVA test was viewed as being more appropriate for comparing why there may be differences between the effects (Wright, 2006), and for being a more powerful procedure (Oakes \& Feldman, 2011). As Wright (2006) stated, ANCOVA is appropriate more often than t-test for analysing differences. Next, the results of the study are presented.

\section{The Results :}

This study investigated the effect of using Web-quest strategy on developing students' reading comprehension 
performance. The scores obtained from the participants' reading comprehension pre- and post-tests were compared. The results are presented in accordance to the research questions, beginning with the first study question. In order to answer the first research question (Will there be a significant improvement in the students' (of both control and experimental groups) comprehension performance in the post reading test at October 6 university?), descriptive analysis and paired samples t-tests were used to investigate any statistically significant differences in the results of the post-test compared with those of the pre-test for both groups. For the control group, Table 2 below reports the paired samples t-test results for comprehension scores.

Table 2

\begin{tabular}{|c|c|c|c|c|c|c|c|}
\hline Group & Variable & test & No. & Mean & St. Deviation & T. Value & $\begin{array}{c}\text { Sig. (2 } \\
\text { Tailed) }\end{array}$ \\
\hline Control & $\begin{array}{c}\text { Reading } \\
\text { Comprehension }\end{array}$ & Pre & 35 & 13.9024 & 5.81264 & $\mathbf{3 . 3 5 4}$ & $\mathbf{0 . 0 0 2}$ \\
\hline & & Post & 35 & 15.2195 & 5.85619 & 3.354 & 0.002 \\
\hline
\end{tabular}

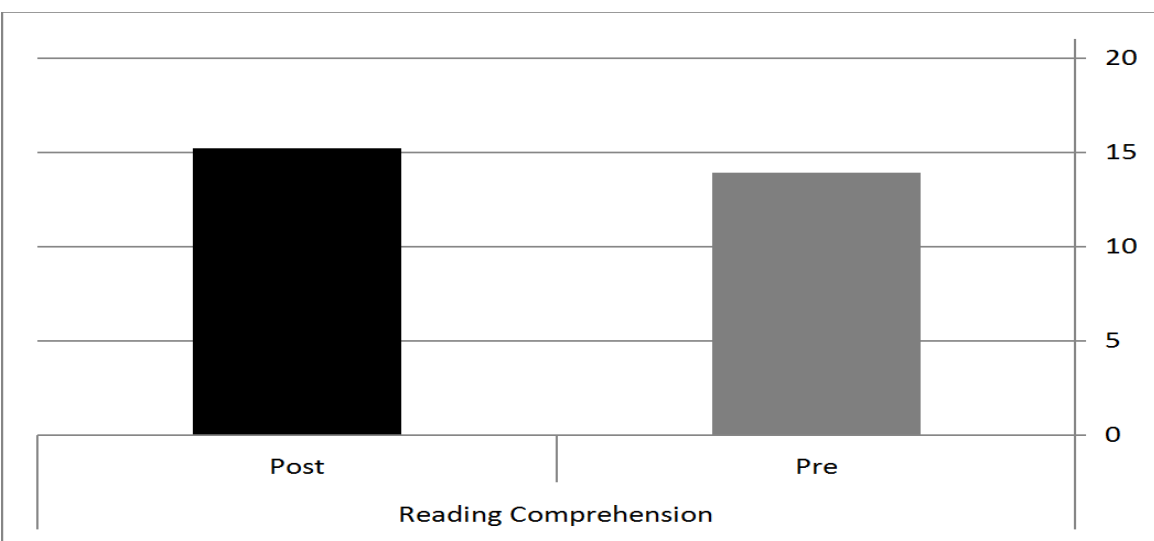

Figure 1. Mean scores of the control group's performance in the pre and post-test for the experimental group, Table 2 below reports the paired samples t-test results for comprehension scores.

Table 2 showed that the performance of the students in the control group improved significantly in reading comprehension scores $[\mathrm{t}=3.354, \mathrm{p}=0.002]$. There are 
significant differences between the two performances in favour of the post-test scores at the level of $p<.01$. These results might be due to the period of conducting the study as it came at the end of the semester. The students who participated in this study, as mentioned before, study in an intensive English course twenty hours per week. Also, the post-test was conducted one week before the final exams period. Figure 1 below showed the overall look of the mean scores of the control group in the pre- and post-test.

For the experimental group, Table 3 below reports the paired samples t-test results for comprehension scores.

Table 3

\begin{tabular}{|c|c|c|c|c|c|c|c|}
\hline Group & Variable & test & No. & Mean & St. Deviation & T. Value & $\begin{array}{c}\text { Sig. (2 } \\
\text { Tailed) }\end{array}$ \\
\hline \multirow{2}{*}{ Experimental } & $\begin{array}{c}\text { Reading } \\
\text { Comprehension }\end{array}$ & Pre & 35 & 13.8571 & 5.85004 & & \multirow{2}{*}{12.600} \\
\cline { 2 - 7 } & & Post & 35 & 20.1429 & 5.74911 & \\
\hline
\end{tabular}

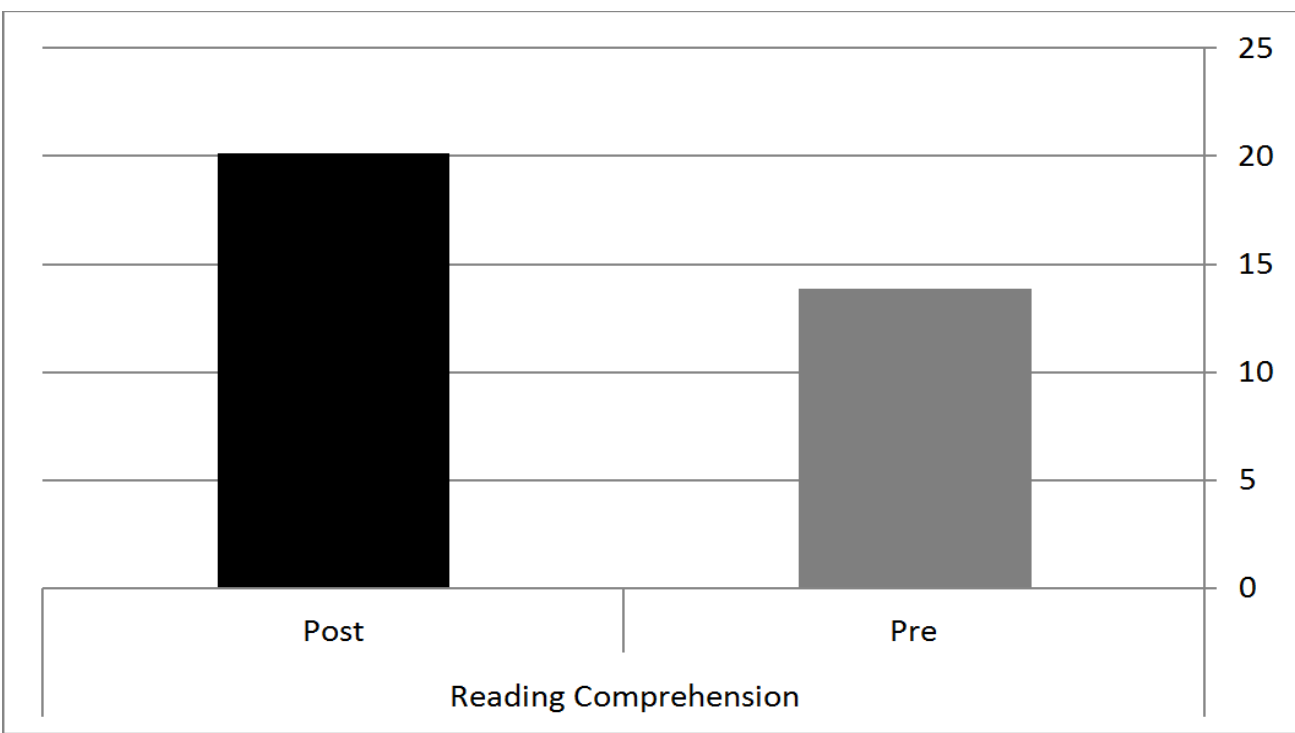

Figure 3. Mean scores of both groups comprehension performance in the post-test. 
The figure shows that the experimental group's mean score is higher than the control group in the post-test. The results will be discussed next in relation to the literature.

Table 3 revealed that the experimental group improved significantly in reading comprehension performance $[\mathrm{t}=$ 8.567, $p=0.000$ ] at the level of $p<.01$ in favour of the posttest results. These results also might be due to the period of applying the study and the intensive program. However, the margin of the mean scores between the mean scores in the pre-test and the post-test is higher in the experimental group than in the control group.The results of both groups showed that there were significant improvements in students' reading comprehension performance over time. However, the treatment effects were investigated in relation to the second research question (Are there any significant differences between the control and experimental groups in the post-tests in relation to the use of Web- quest strategy at October 6 university?). In order to answer the second study question, an analysis of covariance (ANCOVA) was conducted to the pre-test scores.

Table 4

\begin{tabular}{|c|c|c|c|c|c|c|}
\hline Item & Group & No. & Mean & St. Deviation & F & Sig. \\
\hline & Control & $\mathbf{3 5}$ & $\mathbf{1 5 . 2 1 9 5}$ & $\mathbf{5 . 8 6 3 0 7}$ & & \\
\cline { 1 - 5 } & Experimental & $\mathbf{3 5}$ & $\mathbf{2 0 . 1 4 2 9}$ & $\mathbf{5 . 7 4 9 1 1}$ & $\mathbf{6 4 . 8 0 4}$ & $\mathbf{0 . 0 0 0}$ \\
\hline
\end{tabular}

Table 4 showed that there were significant differences between the experimental and control group in the post-test controlling the pre-test scores $[\mathrm{F}=24.286, \mathrm{p}=0.000]$ at the level $\mathrm{p}<.01$. The strongly significant differences occurring in the students' post-test comprehension performance support the claim that using Web-quest can improve students' reading comprehension performance.

\section{Discussion :}

In investigating the effect of using Web-quest strategy on developing reading comprehension performance for EFL students, October 6 University. 


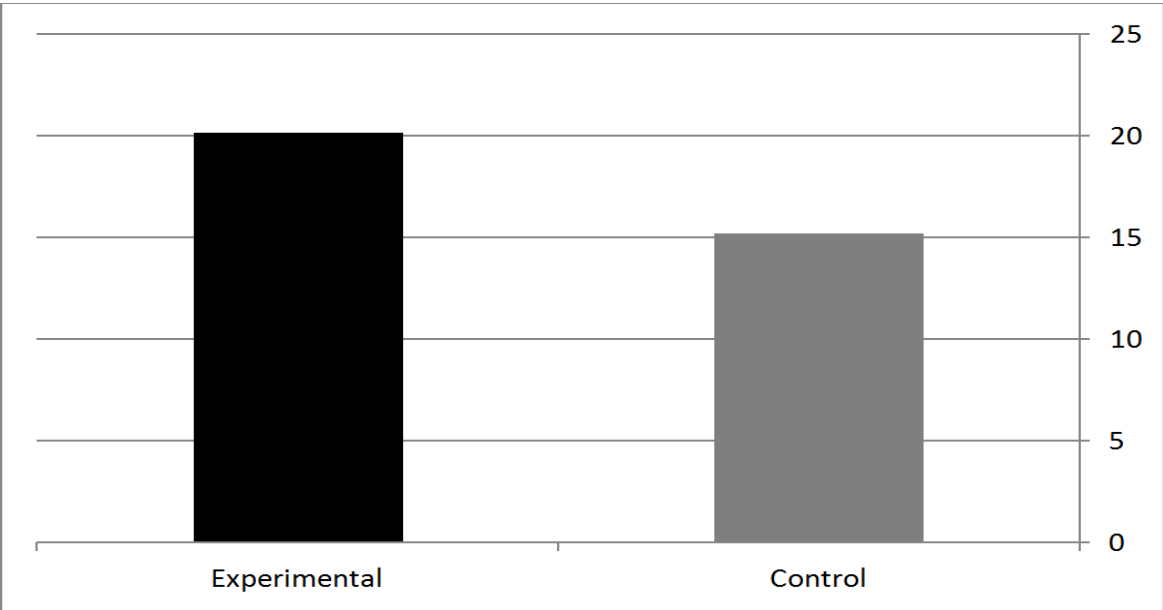

This study found that the performance of the students in the control and the experimental group improved significantly in reading comprehension scores. However, the strongly significant differences occurring in the experimental group's post-test comprehension performance when compared to the pre-test indicate that using Web-quest strategy can improve students' reading comprehension performance.

This study supported the findings of Tsai (2006) who investigated the effect of Web-quest use on the reading vocabulary acquisition and reading performance of Taiwanese EFL university students. Using Web-quests to enhance the normal reading instruction practice in EFL reading courses, Tsai (2006) found that students engaging with Web-quests significantly outperformed those in the control group in both their vocabulary learning and story reading comprehension. Although Tsai (2006) found Webquest in EFL reading instruction may be useful in increasing students' story reading comprehension but not thematic reading comprehension, this research found that thematic Web-quests also can be effective in improving reading comprehension. 
As discussed, previous research on the efficacy of Webquests suggested that the task supports reading comprehension because it requires student analysis, synthesis, evaluation, judgment, problem solving and creativity (Dodge, 2006; Perkins \& McKnight, 2005). The three underlying constructs found by Zheng et. al. (2007) to be critical to the design and related benefits of Webquests are constructivist problem solving, social interaction and scaffold learning. Scaffolding teaching, in which a knowledgeable teacher provides individualized support for students, is a method that aims to build on prior knowledge while internalizing new information or skills. Such as with Web-quest, the task utilized in a scaffold teaching activity should be just beyond the current ability level of the student.

Important to the concept of scaffolded learning is the notion that the support mechanisms of the learning intervention should easily be taken away as the student gains proficiency at the given task. The goal of the teacher is, therefore, to support the student to be an autonomous learner. Web-quests well support this method as the task is designed to motivate students in a blended learning environment by using simple directions to accomplish an activity with clearly defined learning expectations.

Furthermore, as suggested by Zheng et al. (2007), the emphasis of learning via Web-quest could be placed on constructivist learning that incorporates critical thinking and knowledge application. Luźon-Marco (2010) found that Web-quests help students engage with texts related to their discipline by supporting autonomous learning and helping the students become accustomed to the methods of meaning construction needed in digital learning. Similar to the findings of Zheng et al., Barros and Carvalho (2007) found Web-quest to be a valuable environment for teaching 
extensive reading as it can enhance motivation and promote constructivist learning. Similarly, this study supports the theory that Web-quest can be a useful tool in constructivist learning as the method does create an environment in which learning seems relevant, supports the acquisition of skills that are needed in real-world scenarios, and encourages students to analyse information using multiple tools and perspectives.

Reading comprehension, the subject of this study, is dependent on the student's ability to analyse and interpret text. Employing critical thinking skills in order to meaningfully draw connections between newly introduced text and previous knowledge is a crucial step in the development of reading comprehension. Finding that Webquest supports the development of critical thinking, Puthikanon (2013) reported that students actively analysed, synthesized, evaluated, and reflected on information pertaining to the topic of the Web-quest. Although Puthikanon found that low proficiency students struggled to effectively communicate their thoughts in the final products of the Web-quest task, this difficulty does not necessarily reflect the student's ability to comprehend the text or analyse it critically.

Although the teacher's role is to provide the support, or scaffolding, for the learning activity, student engagement in cooperative learning can effectively further the learning process. An environment such as created by Web-quest in which students work in small group settings with teacher assistance can help in reducing the support required from the teacher by the students. Many studies have found that using Web-quest enhanced vital cooperation and collaboration among students (Gorghiu, Gorghiu, González, \& García de la Santa, 2006; Lara \&Repáraz, 2007; Murray \&Mcpherson, 2009; Torres, 2007). This 
aspect of the learning process, and its role in reading comprehension, was not the specific topic of this research, but should be noted as an area in need of further research.

While this study specifically focused on third grade students, previous research has found that students in all grades indicate they prefer Web-quest to traditional teaching methods (Abbitt\&Ophus, 2008; Noordin, Samed\& Razali, 2008; Prapinwong, 2008; Puthikanon, 2009). Gaskill, McNulty and Brooks (2006), while finding no difference in learning outcomes when Web-quests were compared to conventional methods, did reveal that both teachers and students enjoyed Web-quest instruction and the learning environment it created. Although student perceptions were not the focus of this research, general impressions suggest that in agreement with the findings of Vidoni and Maddux (2014), Web-quest can be viewed as an up-to-date strategy that provides knowledge to students in an interesting and interactive way.

\section{Conclusion :}

The results showed the potential of Web-quest use for promoting reading comprehension. Teachers and students do, however, need to be trained in order to use Web-quests more effectively in the blended learning classroom. The students of this study, only needed help to get started on the task and then managed to continue on their own with no difficulty. So, the teachers in general need to be provided with training to explore the usefulness of Webquests and to master its integration in their classrooms. There are challenges inherent in the implementation of Web-quests due to the changing pedagogical principles and practices arising from the use of the tool. Teachers need support in understanding and adjusting to the new way of teaching, especially when they are used to the transmissive mode of instruction. 
Therefore, it is crucial for the teachers to understand the changing role from an authoritative figure to the role of facilitator or mentor as required by the Web-quest design. Also, the use of pre-designed Web-quests in this study may have constrained the teachers in implementation and in choosing interesting topics that meet the needs of the students. The authors suggest that the teacher's experience of the Web-quest tool, and the challenges to its integration in the blended learning classroom, should be investigated further.

The use of Web-Quest seems to be motivating for students as indicated by the teachers in the study. Although this is anecdotal evidence, teachers should invest in the potential of Web-quests as a motivating activity. However, more research is needed. Moreover, the topic and difficulty level of materials are important issues that the teacher should consider when selecting or designing a Web-quest.

March (2014) suggested the teacher choose a topic that the students find compelling and then build an authentic learning task around it. If more than one Web-quest is to be used, the teacher may design topics that seem likely to draw diverse student interest. The type of task should also be designed carefully. If for example, an information gathering task is to be included, it should be used as a step to a more complex task rather than an end in itself.

However, the teacher needs to be careful about the level of difficulty of the tasks and its appropriateness for the students. One limitation of the study was the time constraint in the second term of the academic year 20192020 ( 2 weeks) . Future research should consider longer implementation over one semester, or four months, in order to allow more exposure to Web-quests as well as the possibility to test comprehension at a point other than the 
end of the semester. Also limited by gender, grade level, and level of language ability, this study can be considered a starting point for additional research addressing the use of Web-quest strategy in other educational settings.

Additionally, the study was limited in using a comprehension test as the predictor of reading comprehension. This limitation made it difficult to generalize the results to other contexts. As the study suggested that Web-quest strategy has positive effects on reading comprehension, more qualitative investigation is needed into the processes that students followed that helped enhance reading comprehension.

\section{Recommendations}

As a matter of great concern, EFL prospective teachers have to obtain a clear training concerning the innovative techniques such as; web-quest strategy. Reading comprehension performance should put into consideration that EFL Students should identify this skill in a perfect way. Moreover, there should be a focus on Innovative styles during English courses. Students should be aware of their roles during implementing this strategy. There should further be an explicit training program with the aim of getting the faculty members acquainted with reading comprehension performance aspects in conformity to the ongoing status of teaching at the university level.

Likewise, it is highly recommended that a training program be suggested for the purpose of making students aware of innovative strategies. Furthermore, a research should be done in order to examine the capacity of students that can accommodate and use those innovative strategies for the reason that reading comprehension performance is considered as an important and effective skill that we should concern. 


\section{References :}

Abbitt, J., \&Ophus, J. (2008). What We Know about the Impacts of WebQuests: A Review of Research. AACE Journal, 16(4), 441456.

Al-Issa, A., \& Al-Bulushi, A. (2011). Mere indolence or genuine Hindrance: Paucity of publishing in ELT at Sultan Qaboos University. Cypriot Journal of Educational Sciences, 6(1). Retrieved May 10, 2012, from http://www.world-educationcenter.org/index. php/cjes/article/view/206.

Alshumaimeri, Y. (2008). Perceptions and Attitudes toward Using CALL in English Classrooms among Saudi Secondary EFL Teachers. The JALT CALL Journal, 44(2), 29-66.

Ary, D., Jacobs, L., \&Razavieh, A. (2002). Introduction to Research in Education. USA: Wadsworth-Thomas learning.

Barros, A., \& Carvalho, A. (2007). From a WebQuest to a Reading Quest: learners' reactions in an EFL extensive reading class. Interactive Educational Multimedia, (15), 37-51.

Bravo, E., Enache, M., Fernandez, V., \& Simo, P. (2010). An innovative teaching practice based on online channels: A qualitative approach. World Journal on Educational Technology, 2(2). Retrieved May 10, 2012, from http:// www.world-education-center.org/index.php/wjet/article/view/174.

Cambridge University ESOL Examination. (2010). Preliminary English Test 6 Students' Book with Answers. UK: Cambridge: Cambridge University Press.

Chang, C., Chen, T., \& Hsu, W. (2010). The study on integrating WebQuest with mobile learning for environmental education. Computers \& Education, 57, 1228-1239.

Chuo, T. (2007). The Effects of the WebQuest Writing Instruction. Program on EFL Learners' Writing Performance, Writing Apprehension, and Perception. TESL-EJ-Wenzao Ursuline College of Languages, Taiwan, 11(3). Retrieved from http://tesl-ej.org/ ej43/a3.html.

Cohen, L., Manion, L., \& Morrison, K. (2007). Research methods in education (Sixth ed.). US: New York: Routledge.

Crawford, C., \& Brown, E. (2002). Focusing upon higher order thinking skills: WebQuests and the learnercentered Mathematical learning environment. Retrieved from ERIC databases. (ED474086).

Dewitt, D., \& Siraj, S. (2010). Learners' perceptions of technology for design of a collaborative m-Learning module. World Journal on Educational Technology, 2(3). Retrieved May 10, 2012, fromhttp://www. world-education-center.org/index. php/wjet/article/view/172. 
Dodge, B. (1997). Some Thoughts about WebQuests. San Diego State University. Retrieved April 2, 2010, from http:// webquest.sdsu.edu/about_webquests.html.

Dodge, B. (2006). WebQuests: Past, Present and Future. San Diego State University.

Dudeney, G. (2003). The Quest for Practical Web Usage. The Electronic Journal for English as a Second Language, 6(4). Retrieved March 17, 2010, from http://www.teslej.org/ wordpress/issues/volume6/ej24/ej24int/.

Gaskill, M., McNulty, A \& Brooks, D. (2006). Learning from WebQuests. Journal of Science Education and Technology, 15( 2), 133-136.

Gorghiu, G., Gorghiu, L., González, V.,\& García de la Santa, A. (2006). WebQuest in the Classroom - Analysis of its Impact. Proceedings Book of the 3rd International Conference on Multimedia and Information and Communication Technologies in Education.

Guilloteaux, M., \&Dörnyei, Z. (2008). Motivating Language Learners: A Classroom-Oriented Investigation of the Effects of Motivational Strategies on Student Motivation. TESOL Quarterly, 42(1), 55-77.

Halat, E., \&Peker, M. (2011). The impact of mathematical representations developed through WebQuest and spreadsheet activities on the motivation of pre-service elementary school teachers. The Turkish Online Journal of Educational Technology- TOJET, 10(2), 259-267.

Hassanien, A. (2006). An evaluation of the webquest as a computer-based learning tool. Research in PostCompulsory Education, 11(2), 235-250.

Kern, R. (2006). Perspectives on technology in learning and teaching languages. TESOL Quarterly, 4(1), 183210.

Kocoglu, Z.(2009). WebQuests in EFL reading/writing classroom. Procedia Social and Behavioral Sciences, 2, 3524-3527.

Koenraad, T. (2002). TalenQuest:WebQuest for Modern Languages. Faculty of Education, University of Professional Education of Utrecht, NL.

Koenraad, T., \&Westhoff, G. (2003). Can you tell a LanguageQuest when you see one?: Design criteria for TalenQuests. Paper presented at the 2003 Conference of the European Association for Computer Assisted Language Learning, Limerick, Ireland. Retrieved from http://www.feo.hvu.nl/ koen2/Home/talenquest/TQEurocall.pdf.

Laborda, J. (2009). Using webquests for oral communication in English as a foreign language for Tourism Studies. Educational Technology \& Society, 12(1), 258-270. 
Lara, S. \&Repáraz, C. (2007). Effectiveness of cooperative learning fostered by working with WebQuest. Electronic Journal of Research in Educational Psychology, 13, 5(3).

Limniou, M., \& Whitehead, C. (2010). Online general prelaboratory training course for facilitating first year chemical laboratory use. Cypriot Journal of Educational Sciences, 5(1). Retrieved May 10, 2012, fromhttp://www.world-educationcenter.org/index. php/cjes/article/view/147

Luzon, M. (2007). Enhancing WebQuest for effective ESP learning. Computer Resources for Language Learning, 1, 1-13. Luzón-Marco, M. (2010). Webtasks for Learning Professional and Academic English: Adapting the WebQuest Model. CORELL: Computer Resources for Language Learning, 3, 29-44.

March, T. (2004). What WebQuests Are (Really). The Fulcrum for Systemic Curriculum Improvement, Retrieved April 20, 2010,fromhttp://bestwebquests.com/what webquestsare. asp.

March, T. (2007). Revisiting WebQuests in a Web 2 world: How developments in technology and pedagogy combine to scaffold personal learning. Interactive Educational Multimedia, 15, 1-17.

Murray, D., \&Mcpherson, P. (2009). WebQuest. Using the Web to support language learning (p. 56). Sydney: National Centre for English Language Teaching and Research Macquarie University, Sydney NSW 2109.

Noordin, N., Samad, A., \& Mohamed Razali, A. (2008). ESL Teacher-Trainee Reflections On The Use Of The WebQuest: Practical Or Just A Hype? The English Teacher, University Putra Malaysia, XXXVI, 6680.

Oakes, J, \& Feldman, H. (2001). Statistical power for nonequivalent pretest-posttest designs: The impact of changescore versus ANCOVA models. Evaluation Review, 25, 3-28.

Perkins, R., \& McKnight, M. (2005). Teachers' Attitudes toward WebQuests as a Method of Teaching. The Haworth Press, 22(1), 123-133.

Prapinwong, M. (2008). Constructivist language learning through WebQuests in the EFL context: An exploratory study (Doctoral dissertation). Available from ProQuest Dissertations and Theses database. (UMI No. 3331410).

Prapinwong, M., \&Puthikanon, N. (2007). Constructivist Language Learning through WebQuests in EFL context: The learners' perspectives. Proceedings from the 5th Annual Hawaii International Conference on Education. Honolulu, Hawaii. 
Puthikanon, N. (2009) Examining Critical Thinking and Language Use through the Use of WebQuests in an EFL Reading Class (Doctoral dissertation).Available from Pro Quest Dissertations and Theses database. (UMI No. 3390298).

Samuda, V., \&Bygate, M. (2008). Tasks in second language learning. US: New York: Palgrave Macmillan.

Segers, E., \& Verhoeven, L. (2009). Learning in a sheltered Internet environment: The use of WebQuests. Learning and Instruction, 19, 423-432.

Sen, A., \& Neufeld, S. (2006) In pursuit of alternatives in ELT methodology: WebQuests. The Turkish Online Journal of Educational Technology- TOJET, 5(1), 49-67.

Sox, A., \& Rubinstein-Avila, E. (2009). WebQuests for Englishlanguage learners: Essential elements for design. Journal of Adolescent \& Adult Literacy, 53(1), 38-48.

Strickland, J. (2005). Using WebQuests to Teach Content. State University of West Georgia.

Tavukcu, T., Gezer, F., \&Ozdamli, F. (2009). Determination of the views and success levels towards spread sheets of university students studying with blended learning and e-learning. International Journal of Learning and Teaching, 1, Retrieved May 10, 2012from http:// www.world-educationcenter.org/ index.php/ijlt/ article/ view/325

Torres, I. (2007). WebQuest: a collaborative strategy to teach content and language. University of Granada.

Tsai, S. (2006). Integrating WebQuest learning into EFL instruction. Proceedings from the 2006 Society for Information Technology and Teacher Education Conference. P. 2061-2067.

Tuncay, N., \&Uzunboylu, H. (2011), Faces are better than monitors. International Journal of Learning and Teaching. 3(1), Retrieved May 10, 2012 from http:// www.worldeducationcenter.org/index.php/ijlt/ article/ view/321

Vidoni, K., \& Maddux, C. (2002). WebQuests: Can They Be Used to Improve Critical Thinking Skills in Students? The Haworth Press, 19(1/2), 101-117.

Wright, D. (2006). Comparing groups in a before-after design: When $t$ test and ANCOVA produce different results. British Journal of Educational Psychology, 76(3), 663-675.

Zheng, R., Perez, J., Williamson, J. \&Flygare, J. (2007). WebQuests as perceived by teachers: implications. University of Utah, Salt Lake City, UT, USA. 